\title{
IMPLEMENTASI AL-QUR'AN DAN AL-HADITS PADA ARSITEKTUR ANDALUSIA
}

\begin{abstract}
Al-Quran is the final revelation that guide human's life, not only for Muslims, but also for non-Muslim people. Meanwhile, al-Hadith contains explanations from the Prophet Muhammad pbuh about the Qur'an. Both of them provide the way of life for the whole mankind, not only in the interests of the afterlife, but also in the worldly life. Architecture as one of a human worldly need should also reflect on the values within the Qur'an and Hadith. One of the values that related to architecture is the beauty. This paper aims to show the implementations of the Qur'an and Hadith in the beauty aspect of Islamic architecture in Andalucia.
\end{abstract}

Keywords: al-Qur’an, al-Hadith, Islamic architecture, beauty, Andalucia

\begin{abstract}
Abstrak
Al-Qur'an yang merupakan firman Allah SWT adalah sebuah pedoman hidup untuk manusia yang ditujukan tidak hanya untuk umat muslim saja, melainkan juga untuk umat non muslim. Sedangkan al-Hadits adalah sebuah sabda Rasulullah Muhammad SAW yang menjelaskan isi al-Qur'an. Kedua kitab ini memberikan petunjuk hidup untuk umat manusia, tidak hanya pada kepentingan akhirat, melainkan juga kehidupan dunia. Arsitektur yang merupakan kebutuhan manusia di dunia sebaiknya juga bercermin pada nilai-nilai yang terkandung pada kedua kitab tersebut. Salah satu nilai yang berkenaan dalam arsitektur adalah keindahan. Contoh bangunan yang mencerminkan keindahan tersebut adalah bangunan-bangunan di Andalusia.
\end{abstract}

Kata kunci: al-Qur’an, al-Hadits, arsitektur Islam, Keindahan, Andalusia

\section{Pendahuluan: Perkembangan Arsitektur Islam di Andalusia, Spanyol}

Bangunan-bangunan Islam yang terdapat di Andalusia, bagian selatan Spanyol, memberikan bukti kuat bahwa Islam pernah berpengaruh di Eropa. Bangunan Islam yang didirikan antara tahun 711 hingga 1492 masehi di beberapa kota di Andalusia merupakan bangunan yang mengimplementasikan nilai-nilai al-Qur'an dan al-Hadits pada tiap-tiap bangunannya. Masa itu adalah masa keemasan Islam di mana bangunan-bangunan yang didirikan semua bernafaskan Islam, mulai dari bentuk arsitekturnya hingga dekorasi yang menghiasi eksterior dan interior bangunan.

Islam melarang adanya gambar binatang dan manusia sebagai dekorasi, oleh karena itu kesenian dalam bentuk kaligrafi, geometri, dan motif tumbuhan adalah beberapa contoh motif dekorasi yang digunakan pada pola berkesenian Islam pada saat itu. Contoh motif dekorasi yang dimaksud terdapat pada Gambar 1 - 3. Motif tersebut dapat ditemukan pada bagian atap, dinding bagian dalam dan luar bangunan, lantai, karpet, keramik, gelas, serta piring. Contoh motif tersebut terdapat pada Gambar 4.
Gambar 1. Motif pada Dinding Real Alcazar di Sevilla yang dibuat dengan Geometri (Sumber: Dokumentasi Pribadi)

Taman yang merupakan bagian luar dari bangunan juga tidak pernah ketinggalan dalam suatu kawasan bangunan Islam. Terkadang taman tersebut menyatu dalam lingkup kawasan, namun terkadang terpisah dari bangunan. Taman yang menyatu dalam satu kawasan bangunan dapat dijumpai di Alhambra (Granada), Real Alcazar (Jerez de la Frontera), Alcazaba (Malaga), dan Masjid Cordoba.

Sementara itu, pada Masjid-Katedral di Sevilla, taman Real Alcazar terletak beberapa meter dari situs bangunan, namun dari ciri bangunan Islam yang 
ada di Andalusia, sisi taman tidak pernah lepas dari bangunan yang ada ${ }^{1}$.

Lalu apa yang menghubungkan al-Qur'an, alHadits, dan bangunan yang ada di Andalusia? Jawabannya ada pada implementasi dari al-Qur'an dan al-Hadits terhadap bangunan tersebut.

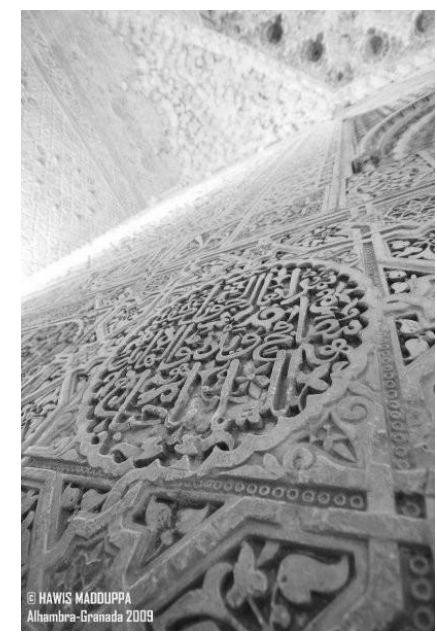

Gambar 2. Kaligrafi yang Dikelilingi Motif Ulir pada Dinding Alhambra di Granada (Sumber: Hawis Maduppa)

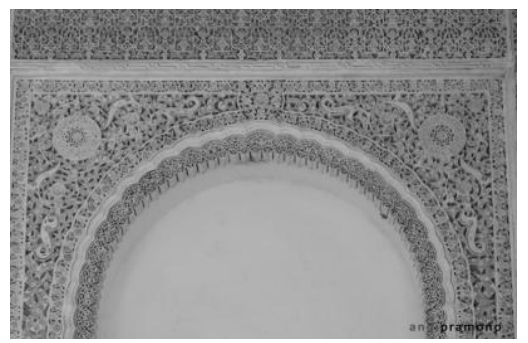

Gambar 3. Motif Ulir pada Dinding Interior Real Alcazar di Sevilla (Sumber: Dokumentasi Pribadi)

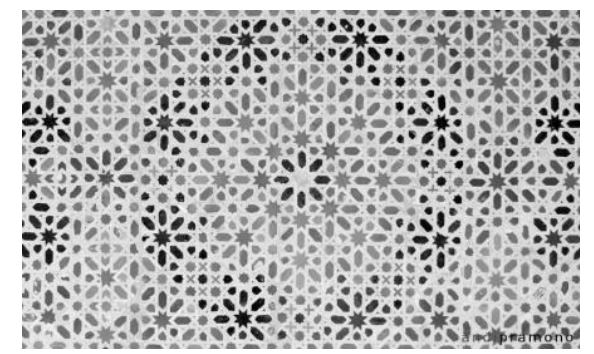

Gambar 4. Penerapan Geometri pada Keramik yang Menghiasi Dinding (Sumber: Dokumentasi Pribadi)

Allah menciptakan langit dan bumi. Hal itu juga menggambarkan bahwa kita akan mengalami dua kehidupan, yaitu kehidupan dunia yang bersifat sementara dan kehidupan akhirat yang bersifat kekal. Kehidupan sementara sedang kita rasakan, sedangkan kehidupan akhirat akan kita rasakan. Kehidupan akhirat akan terbagi lagi menjadi dua bagian, yaitu surga dan neraka. Sebagai orang muslim yang beriman, tentunya kita mendambakan kehidupan di surga. Keindahan surga yang dijanjikan oleh Allah swt tertulis dalam ayat-ayat al-Qur'an dan diperjelas di dalam al-Hadits.

Manusia sebagai ciptaan Allah yang diberi kesempurnaan ruh, rasa, hati, akal, dan nafsu berupaya untuk menciptakan sebuah keindahan yang disukai oleh Allah. Bagaimana menciptakan keindahan tersebut, manusia yang dalam hal ini adalah arsitek, berupaya untuk menerjemahkan kalimat-kalimat Allah di dalam al-Qur'an ke dalam bangunan di dunia.

\section{Implementasi Sifat-Sifat Surga dalam al-Qur'an dan al-Hadits pada Arsitektur}

Allah itu indah dan mencintai keindahan, begitu yang disabdakan Rasulullah Muhammad saw. Kalimat ini mengandung makna yang sangat dalam tentang arti keindahan. Allah menciptakan semua makhlukNya beserta dunia dan seluruh isinya dengan penuh keindahan, baik itu di dunia ataupun di akhirat nantinya. Kita sebagai manusia bisa menilai sendiri bagaimana kesempurnaan ciptaan-Nya yang bisa kita lihat dan kita nikmati saat ini di dunia.

Memang kita belum dapat merasakan keindahan yang ada setelah kita mati, yaitu keindahan di surga. Namun, Allah telah memberikan petunjuk bagaimana keindahan di surga nantinya, sebagaimana telah disebutkan dalam berbagai ayat di dalam al-Qur'an, sebagai berikut:

\section{Surat al-Hijr Ayat $45-48$}

"Sesungguh orang-orang yang bertakwa itu dalam taman-taman surga dan (dekat) mata air (yang mengalir). Dikatakan kepada mereka, masuklah ke dalamnya dengan sejahtera dan aman. Dan kami lenyapkan segala rasa dendam yang ada dalam hati mereka, mereka merasa bersaudara, duduk berhadaphadapan di atas dipan-dipan, mereka tidak merasa lelah di dalamnya dan mereka tidak akan dikeluarkan darinya."

\section{Surat al-Kahfi Ayat 30-31}

"Sesungguhnya mereka yang beriman dan beramal sholeh, tentulah Kami tidak menyia-nyiakan pahala orang-orang yang mengerjakan amal(nya) dengan baik. Mereka itulah orang-orang yang mendapatkan surga 'Adn, sungai-sungai mengalir di bawahnya, dalam surga itu mereka diberi perhiasan gelang emas dan mereka memakai pakaian hijau dari sutera halus dan tebal dan mereka duduk sambil bersandar di atas dipan-dipan yang indah, itulah pahala yang sebaik-baiknya dan tempat istirahat yang indah."

\section{Surat Shaad Ayat 49-54}

"Ini adalah kehormatan (bagi mereka) dan sesungguhnya bagi orang-orang bertakwa benar-benar (disediakan) tempat kembali yang baik (yaitu) surga 'Adn yang pintu-pintunya terbuka bagi mereka. Di dalamnya mereka bertelekan (di atas dipan-dipan) sambil meminta buah-buahan yang banyak dan meminum di dalamnya. Dan pada sisi mereka lada 
bidadari) yang tidak liar pandangannya dan sebaya umurnya. Inilah apa-apa yang dijanjikan kepadamu pada hari berhisab. Sesungguhnya ini adalah benarbenar rezeki dari Kami yang tiada habis-habisnya."

\section{Surat ad-Dukhaan Ayat 51-57}

"Sesungguhnya orang-orang bertakwa berada pada tempat yang aman (yaitu) dalam taman-taman dan mata air. Mereka memakai sutera yang tebal, (duduk) berhadap-hadapan. Demikianlah, dan Kami berikan kepada mereka bidadari. Di dalamnya mereka meminta segala macam buah-buahan dengan aman (dari segala kekhawatiran), mereka tidak akan pernah merasakan mati di dalamnya, kecuali mati di dunia, dan Allah memelihara mereka dari siksa neraka sebagai karunia dari Tuhanmu, yang demikian itu adalah keberuntungan yang besar. ${ }^{"}$

\section{Surat al-Waaqi'ah Ayat 13-38}

"Segolongan besar dari orang-orang terdahulu dan segolongan kecil dari orang-orang kemudian, mereka bertahtakan emas dan permata, seraya bertelekan di atasnya berhadap-hadapan, mereka dikelilingi oleh anak-anak muda dengan membawa teko (cerek), cangkir-cangkir berisi minuman yang diambil dari air yang mengalir, mereka tidak pusing meminumnya dan tidak pula mabuk, dan buah-buahan dari apa-apa yang mereka pilih dan daging burung dari apa yang mereka inginkan. Dan di dalamnya ada bidadari yang bermata jeli laksana mutiara yang tersimpan baik, sebagai balasan bagi apa yang mereka kerjakan. Di dalamnya mereka tidak mendengar perkataan yang sia-sia dan tidak pula perkataan yang menimbulkan dosa, akan tetapi mereka hanya mendengar ucapan salam. Dan golongan kanan. Alangkah bahagianya, golongan kanan itu berada di antara pohon-pohon bidara yang tidak berduri dan pisang-pisang yang bersusun-susun buahnya dan naungan yang terbentang luas dan air yang tercurah dan buah-buahan yang banyak yang tidak berhenti. Dan sesungguhnya Kami menciptakan mereka (bidadari-bidadari) dengan langsung dan Kami jadikan mereka gadis-gadis perawan yang penuh cinta lagi sebaya umur mereka. Kami ciptakan mereka untuk golongan kanan."

6. Surat al-Haaqqoh Ayat 19-28

"Adapun orang-orang yang diberikan kitab (buku catatan amal)nya dari sebelah kanan, maka dia berkata, ambilah, bacalah kitabku ini. Sesungguhnya aku yakin bahwasanya aku akan menemui hisab terhadap diriku. Maka orang itu berada dalam kehidupan yang diridhoi dalam surga yang tinggi, buahbuahnya dekat (kepada mereka), lalu dikatakan kepada mereka, makan dan minumlah dengan sedap disebabkan amal yang kalian kerjakan pada hari-hari yang telah berlalu (dunia)."

\section{Surat al-Insaan ayat 11-15}

"Maka Tuhan memelihara mereka dari kesusahan hari itu dan menjadikan muka mereka berseri-seri dan kegembiraan hati. Dan Dia memberi balasan kepada mereka, karena kesabaran mereka dengan surga dan pakaian sutera, di dalamnya mereka tidak merasakan terik matahari dan tidak pula dingin yang menyengat. Dan naungan (pohon-pohon) surga itu dekat di atas mereka dan buahnya dimudahkan untuk memetiknya dengan semudah-mudahnya. Dan diedarkan kepada mereka bejana-bejana dari perak dan piala-piala yang bening laksana kaca, yaitu kaca-kaca yang yang terbuat dari perak yang telah mereka diukur dengan sebaik- baiknya. Dalam surga itu mereka diberi minum segelas minuman yang campurannya adalah jahe, sebuah mata air surga yang dinamakan salsabil."

Dari beberapa ayat di dalam al-Qur'an yang telah disebutkan di atas, dapat ditarik kesimpulan bahwa surga memiliki sifat-sifat, antara lain memiliki taman-taman, buah-buahan, mata air yang mengalir, sungai yang mengalir, dan pepohonan. Beberapa sifat yang disebutkan di atas, sang arsitek mencoba menghadirkannya ke dalam bangunanbangunan Islam yang terdapat di Andalusia. Beberapa taman yang terdapat pada bangunan Islam di Andalusia memiliki ciri-ciri yang sama, yaitu penempatan air mancur pada perempatan jalan taman, menghadirkan pohon-pohon tinggi sebagai peneduh, semak yang dirias untuk memberikan border pada jalan di taman, dan menghadirkan pohon buah jeruk sebagai pelengkap taman. Contoh desain tersebut terdapat pada Gambar 5 - 8 berikut.

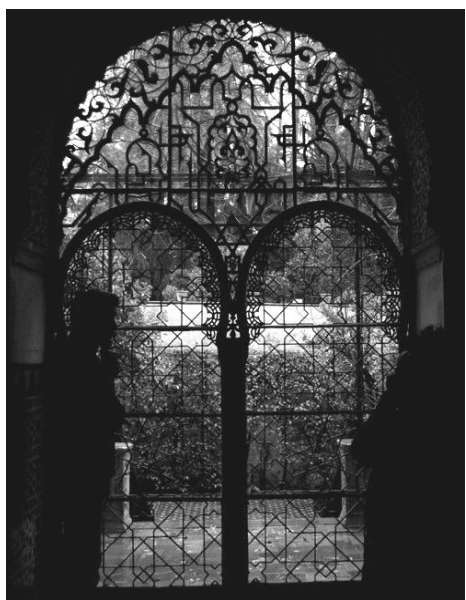

Gambar 5. Taman Real Alcazar di Sevilla (Sumber: Dokumentasi Pribadi)

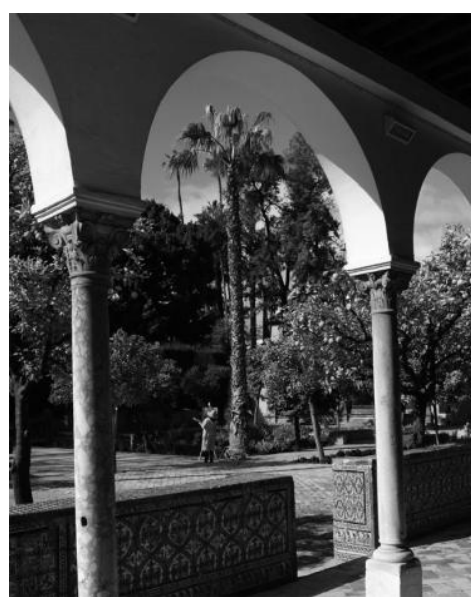

Gambar 6. Pepohonan di Taman Real Alcazar di Sevilla (Sumber: Andi Pramono)

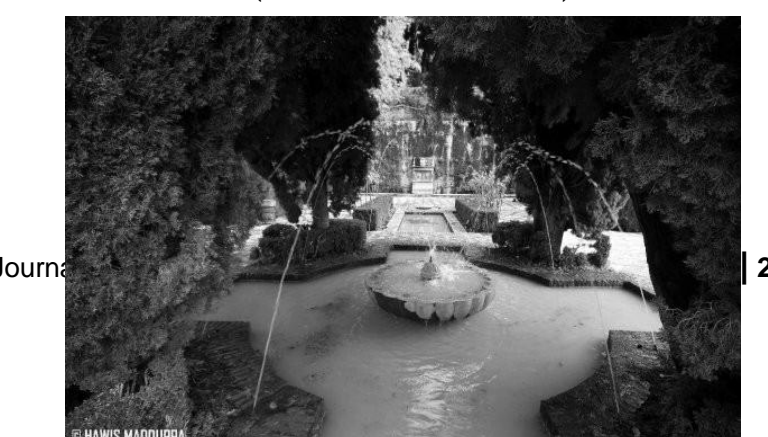


Gambar 7. Air Mancur pada Taman Alhambra di Granada (Sumber: Hawis Maduppa)

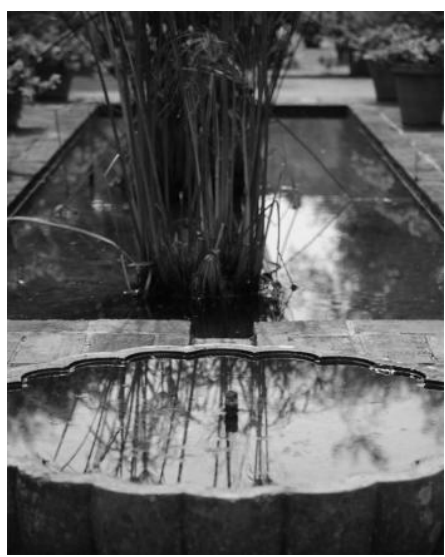

Gambar 8. Air Mancur pada Taman Real Alcazar di Jerez de La Frontera (Sumber: Andi Pramono)

Sifat-sifat surga juga diperjelas oleh Rasulullah saw melalui sabda yang diriwayatkan di dalam alHadits, sebagaimana disebutkan oleh Mujahid bahwa dasar surga (landasannya) adalah perak, debunya misik, akar-akaran pohonnya adalah perak, batang pohon/dahannya mutiara dan zabarjad, daun dan buahnya sangat rendah, makan buahnya dengan cara apa saja bisa, baik berdiri, duduk ataupun berbaring tidak sulit. ${ }^{9}$ Hadits lain yang menyebutkan sifat surga sebagaimana dijelaskan dari Abu Hurairah: "Kami bertanya: 'Ya Rasul, sorga itu diciptakan dari apa?' Jawab beliau: 'Dari air,' lalu jelaskan bangunannya kepada kami. Kata beliau: 'Dinding pertama emas, kedua perak, dan lantainya kasturi sangat harum, dasarnya za'faran, kerikilnya mutiara dan yakut, Barang siapa yang memasukinya langsung lega hatinya dan kekal tanpa batas pati, pakaiannya tidak mengenal lapuk dan wajahnya tidak pernah mengalami perubahan"10.

Di dalam salah satu hadits juga disebutkan bahwa di surga terdapat sebuah pohon yang bayangannya tidak putus dalam seratus tahun. Kita bisa membayangkan betapa rindangnya satu pohon di surga tersebut sehingga memiliki bayangan dengan jangkauan seratus tahun tidak putus. Memang apabila dipikir dengan logika, kita belum pernah melihat pohon serindang itu.

\section{Kesenian Islam yang Bersumber dari al-Qur'an}

Kesenian dalam bentuk lukisan merupakan sebuah karya seni yang sering kali dipajang pada interior bangunan. Begitu juga seni pahat yang pada umumnya berupa patung yang diletakkan pada interior dan eksterior bangunan.

Kesenian Bizantium merupakan sebuah karya seni yang sangat terkenal di masa itu. Pelukis tidak hanya menghadirkan lukisan di dalam kanvas, melainkan juga menuangkan ide kreatifnya pada dinding dan atap atau kubah bangunan. Lukisan bergambar sosok manusia, hewan, sering kali terlihat pada berbagai karya seni dari Bizantium tersebut. Begitu juga dengan seni pahat, sosok manusia dan hewan kerap kali terlihat pada dinding bangunan, kolom bangunan, dan juga patung yang terletak di bagian dalam dan luar bangunan.

Karya seni ini memiliki pengaruh yang kuat, namun kesenian yang menghadirkan sosok manusia dan binatang ini sangatlah dilarang dalam Islam. Sebagai wujud kecintaan dan kepatuhan seorang insan muslim terhadap Allah Sang Penciptanya, larangan itu tidak disikapi sebagai kungkungan bagi kreativitas dan penghalang untuk menciptakan sebuah keindahan. Sebaliknya, mereka mengeksplorasi berbagai keindahan di dalam dan di dalam ilmu yang telah dianugerahkan kepada mereka untuk menghasilkan keindahan yang tidak bertentangan dengan larangan-Nya.

Ilmu geometri adalah ilmu matematika yang sangat terkenal saat itu di Spanyol, terutama Cordoba sebagai pusat keilmuan dan peradaban di Barat. Ilmu geometri ini dimanfaatkan untuk menciptakan sebuah kesenian dipadu dengan kaligrafi untuk menyanjung kebesaran-Nya. Sebagai pemercantik kedua kesenian itu, dihadirkan pula motif tumbuhan. Contoh motif tersebut bisa dilihat pada Gambar 9.

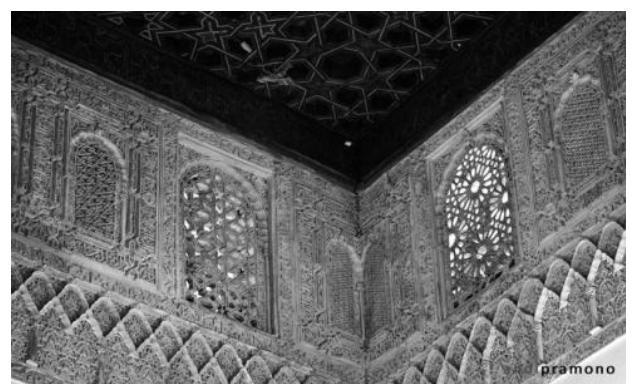

Gambar 9. Geometri, Kaligrafi, dan Motif Tumbuhan adalah Tiga Kesenian Islam (Sumber: Andi Pramono)

Geometri merupakan salah satu bagian dari ilmu matematika yang sering kali diimplementasikan pada bangunan-bangunan di Andalusia. Ilmu ini tidak hanya digunakan untuk ornamen, melainkan juga digunakan untuk membuat desain layout, fasade, dan denah bangunan, serta layout taman ${ }^{11}$. Contoh desain terdapat pada Gambar 10 - 12. 


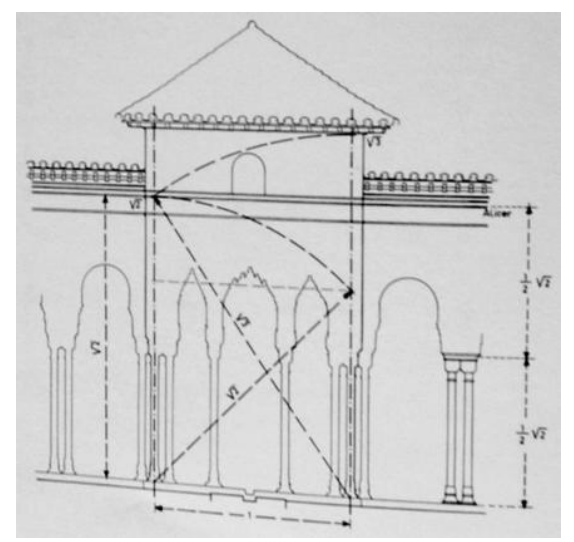

Gambar 10. Menentukan Ketinggian Fasade dengan Sistem Akar 3 (Sumber: Puertas ${ }^{12}$ )

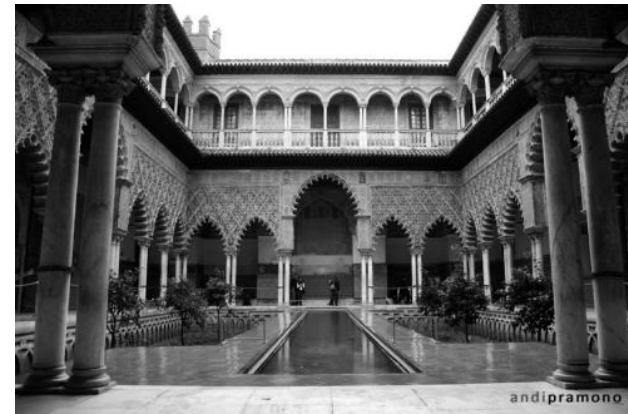

Gambar 11. Fasade pada Bangunan Real Alcazar Sevilla yang Kemungkinan juga Didesain dengan Geometri (Sumber: Dokumentasi Pribadi)

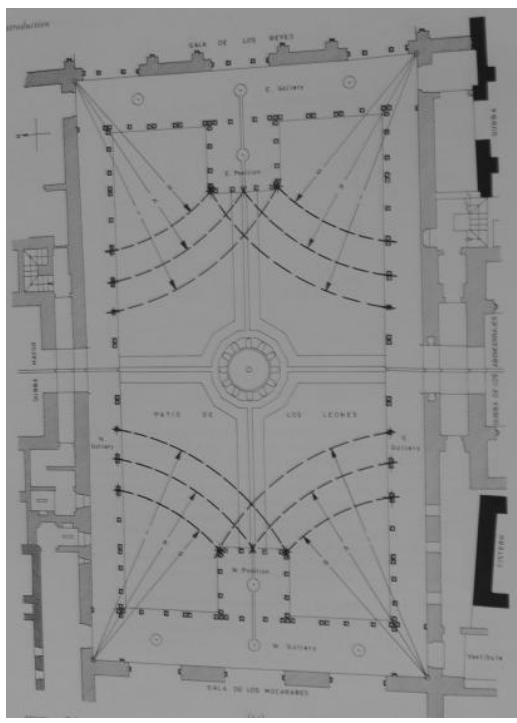

Gambar 12. Menentukan Layout pada Taman dengan Geometri (Sumber: Puertas)

Dasar dari seni geometri ini adalah lingkaran. Beberapa lingkaran yang terhubung satu sama lain akan terbentuk sebuah titik. Dari titik-titik tersebut dapat ditarik sebuah garis. Garis-garis itulah yang nantinya diulang pada lingkaran yang lain dan akan terbentuk sebuah motif. Hal ini ditunjukkan pada Gambar 13.

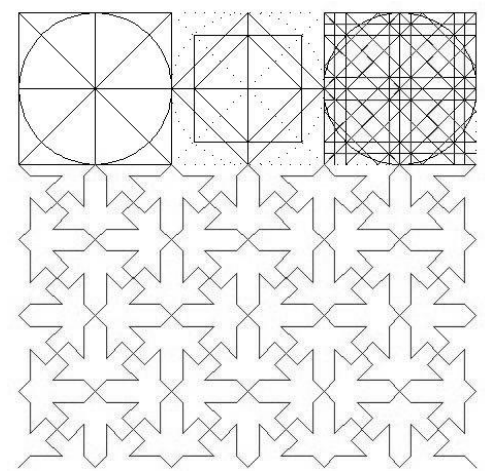

Gambar 13. Motif yang Dibentuk dengan Dasar Lingkaran Sistem Proporsi Akar 2 (Sumber: El-Said ${ }^{13}$ )

Teknik yang digunakan untuk membuat sebuah lingkaran adalah teknik bandul, yaitu diletakkan sebuah paku yang menancap sebagai titik pusat lingkaran. Selanjutnya dihubungkan dengan benang yang ujungnya terdapat pensil. Ketika pensil itu diayunkan, maka akan terbentuklah sebuah lingkaran ${ }^{14}$.

Dari dasar sebuah lingkaran juga dapat digunakan untuk membuat ornamen tumbuhtumbuhan. Lingkaran-lingkaran yang berpotongan satu sama lain akan terbentuk garis imajiner dan dari garis imajiner tersebut dibuat garis tegas untuk membentuk sebuah gambar dedaunan yang proporsi.

Selain digunakan untuk membuat motif-motif itu sendiri, teknik geometri juga dimanfaatkan dalam menentukan bentuk simetri dan proporsi pada kaligrafi dan motif tumbuhan. Peran ini sangat kuat sekali dalam kesenian Islam. Dengan demikian, tidak salah apabila motif-motif yang dibuat dari ilmu geometri ini adalah kesenian khas Islam, yang mana pada kesenian ini tidak menghadirkan sosok manusia dan binatang. Kesenian yang murni hadir dari pemikir dan desainer Islam untuk menciptakan keindahan.

\section{Penutup}

Bangunan Islam yang didirikan antara tahun 711 hingga 1492 Masehi di beberapa kota di Andalucia merupakan bangunan yang mengimplemenasikan nilai-nilai al-Qur'an dan al-Hadits pada tiap-tiap bangunannya. Keindahan merupakan kata kunci yang digunakan untuk memberikan nafas pada bangunan. Hal ini tercermin pada desain yang selalu menghadirkan taman untuk menyajikan kenyamanan dan kesejukan bagi penghuninya. Kesenian geometri, kaligrafi, dan motif tumbuhan dihadirkan sebagai kekayaan khasanah keindahan untuk mengagungkan asma-Nya tanpa melanggar ketentuan-ketentuan 
yang telah digariskan-Nya di dalam al-Qur'an dan alHadits.

\section{Referensi}

1 D. Fairchild Ruggles. 2002. Gardens, Landscape and Vision in the Palaces of Islamic Spain. Pennsylvania: Pennsylvania State University Press

2 Yayasan Penyelenggara Penerjemah al-Qur'an. 2005. Mushaf al-Qur'an Terjemah. Surat 15: 4548. Jakarta: Penerbit Al-Huda

3 Yayasan Penyelenggara Penerjemah al-Qur'an. 2005. Mushaf al-Qur'an Terjemah. Surat 18: 30 31. Jakarta: Penerbit Al-Huda

4 Yayasan Penyelenggara Penerjemah al-Qur'an. 2005. Mushaf al-Qur'an Terjemah. Surat 38: 4954. Jakarta: Penerbit Al-Huda

5 Yayasan Penyelenggara Penerjemah al-Qur'an. 2005. Mushaf al-Qur'an Terjemah. Surat 44: 51 57. Jakarta: Penerbit Al-Huda

6 Yayasan Penyelenggara Penerjemah al-Qur'an. 2005. Mushaf al-Qur'an Terjemah. Surat 56: 1338. Jakarta: Penerbit Al-Huda

7 Yayasan Penyelenggara Penerjemah al-Qur'an. 2005. Mushaf al-Qur'an Terjemah. Surat 69: 1928. Jakarta: Penerbit Al-Huda

8 Yayasan Penyelenggara Penerjemah al-Qur'an. 2005. Mushaf al-Qur'an Terjemah. Surat 76: 11 . 15. Jakarta: Penerbit Al-Huda

9,10 http://ahnaaf.wordpress.com/2009/12/09/beginilah-gambaran-penghuni-surga-dalam-alquran-sunnah/

11 Felix Escrig. 2009. Geometry and Structures. Historical Impresions about architecture. Valencia: J. IASS

12 Antonio Fernandez Puertas. 1997. The Alhambra from the Ninth Century to Yusuf I (1354). London: Saqi Books

13 Issam El-Said. 1993. Islamic Art and Architecture. The System of Geometric Design. United Kingdom: Garnet Publishing Limited

14 Issam El-Said. 1993. Islamic Art and Architecture. The System of Geometric Design. United Kingdom: Garnet Publishing Limited 